\title{
An HR-Induced Tobacco Peroxidase Gene Is Responsive to Spermine, but Not to Salicylate, Methyl Jasmonate, and Ethephon
}

\author{
Susumu Hiraga, ${ }^{1,4}$ Hiroyuki Ito, ${ }^{1}$ Hiromoto Yamakawa, ${ }^{2,4}$ Norihiro Ohtsubo, ${ }^{4}$ Shigemi Seo, ${ }^{4}$ \\ Ichiro Mitsuhara, ${ }^{3,4}$ Hirokazu Matsui,, ${ }^{1}$ Mamoru Honma, ${ }^{1}$ and Yuko Ohashi ${ }^{3,4}$ \\ ${ }^{1}$ Department of Applied Bioscience, Graduate School of Agriculture, Hokkaido University, Sapporo, \\ Hokkaido, 060-8589 Japan; ' Institute of Biological Sciences, University of Tsukuba, Tsukuba, Ibaraki, \\ 305-8572 Japan; ${ }^{3}$ Department of Molecular Genetics, National Institute of Agrobiological Resources, \\ Tsukuba, Ibaraki, 305-8602 Japan; ${ }^{4}$ Core Research for Evolutional Science and Technology (CREST), \\ Chiyoda-ku, Tokyo 101-0062, Japan \\ Accepted 18 October 1999.
}

In Tobacco mosaic virus (TMV)-infected tobacco plants carrying the $N$ resistance gene, a hypersensitive reaction or response (HR) occurs to enclose the virus in the infected tissue. Although a contribution of peroxidases to the resistance has been proposed, no evidence has been presented that tobacco peroxidase genes respond to HR. Here, we describe the HR-induced expression of a tobacco peroxidase gene (tpoxC1) whose induction kinetics were slightly different from those of acidic and basic tobacco pathogenesis-related (PR) protein genes. Interestingly, tpoxC1 was insensitive to the inducers of PR genes such as salicylic acid, methyl jasmonate, and ethephon. Spermine activated tpoxC1 gene expression at a low level and both acidic and basic PR gene expression at a considerably higher level. These results indicate that the induced expression of tpoxC1 is regulated differently from that of classical tobacco PR genes in the $N$ gene-mediated selfdefense system in tobacco plants.

Additional keyword: wounding.

In the interactions between Tobacco mosaic virus (TMV) and resistant tobacco cultivars carrying the $N$ gene, infected tissues display a hypersensitive reaction or response (HR) that is associated with necrotic lesion formation to enclose the virus at the infected site. This phenomenon is characterized by diverse responses such as accumulations of salicylic acid (SA) (Malamy et al. 1990), jasmonic acid (JA) (S. Seo and Y. Ohashi, unpublished), ethylene (Ohtsubo et al. 1999), and spermine (Spm) (Yamakawa et al. 1998), callose deposition (Shimomura and Dijkstra 1975) and induction of pathogenesis-related (PR) proteins, which are the plant proteins induced in pathological or related situations (van Loon et al. 1994).

Corresponding author: Yuko Ohashi; Department of Molecular Genetics, National Institute of Agrobiological Resources, Tsukuba, Ibaraki, 3058602 Japan; Telephone: +81-298-38-7440; Fax: +81-298-38-7469; E-mail: yohashi@ss.abr.affrc.go.jp

Current address of N. Ohtsubo: National Agriculture Research Center, Tsukuba, Ibaraki, 305-8666 Japan.
PR proteins are proposed to be classified into 14 families on the basis of structural and functional properties (van Loon and van Strien 1999) and, in tobacco plants, expression profiles of five classical PR families (PR-1 to PR-5) have been studied in detail. They are composed of acidic and basic types, originally classified by their isoelectric points (Memelink et al. 1990; Brederode et al. 1991; Ohashi and Ohshima 1992). Genes for basic PR proteins are induced by wounding, and JA enhances (Brederode et al. 1991; Niki et al. 1998) while SA inhibits (Niki et al. 1998) their expression. In contrast, the expression of genes for acidic PR proteins is induced by SA but not by wounding (Brederode et al. 1991; Ward et al. 1991; Niki et al. 1998), and the effect of SA is inhibited in the presence of JA (Niki et al. 1998). Recently, Spm, which accumulates in the intercellular spaces of TMV-infected tobacco leaves developing necrotic lesions, was proposed to be an endogenous inducer of acidic PR-1, $-2,-3$, and -5 proteins and to confer resistance to TMV infection (Yamakawa et al. 1998). However, few studies have reported on the expression profiles of PR proteins other than the classical PR-1 to PR-5 and PR-6 families in tobacco.

Class III plant peroxidases (POXs; EC 1.11.1.7), which catalyze the oxidoreduction of hydrogen peroxide and various reductants, have been shown to be induced in pathological interactions involving plants and fungi (Thordal-Christensen et al. 1992; Harrison et al. 1995), bacteria (Reimers et al. 1992), viruses (van Loon and Geelen 1971; Lagrimini and Rothstein 1987), and a viroid (Vera et al. 1993). POX consists of multiple molecular forms (isoPOX) in single plant species, some of which do not respond to pathogen infection; therefore, only specific pathogen-inducible isoPOXs have been categorized in the PR-9 family (van Loon et al. 1994). Several studies have indicated an association of enhanced POX activity and induced resistance to TMV infection (Simons and Ross 1970) and Pseudomonas syringae pv. tabaci infection (Lovrekovich et al. 1968) in tobacco plants. In rice, an incompatible interaction with Xanthomonas oryzae pv. oryzae causes a more rapid and enhanced induction of a cationic POX than a compatible interaction (Reimers et al. 1992). In the defense system of plants against pathogen attack, POXs are pro- 
posed to contribute essentially to the construction of strengthened physical barriers in cell walls (Vance et al. 1980; Fry 1986; Bowles 1990), formation of active oxygen species (Bolwell et al. 1995; Wojtaszek 1997), and production of antimicrobial substances (Kristensen et al. 1999). The induction of multiple isoPOXs in a single host-parasite interaction (Harrison et al. 1995; Chittoor et al. 1997) may reflect a contribution by each isoPOX to a specific process in the induced resistance.

Pathogen-inducible POX genes have been shown to be induced by defense-related signal compounds such as abscisic acid in tomato (Roberts and Kolattukudy 1989), jasmonates in rice (Schweizer et al. 1997) and Stylosanthes humilis (Curtis et al. 1997), SA in cucumber (Rasmussen et al. 1995) and parsley (Thulke and Conrath 1998), and ethephon, an ethylene-releasing agent, in tomato (Vera et al. 1993).

In tobacco, at least 12 isoPOXs were detected by activity staining after isoelectric focusing (Lagrimini and Rothstein 1987). Among them, two anionic isoPOXs (pI 3.5 and 3.75, respectively) were found to be the major isoPOXs in most organs and constitutively expressed in leaves (Lagrimini and Rothstein 1987). Analyses of transgenic plants over- or underproducing the anionic POX (Lagrimini 1991; Lagrimini et al. 1997a, 1997b) and the catalytic properties of purified enzyme (Gazaryan and Lagrimini 1996) suggested that this POX is associated with auxin degradation and the metabolism of phenolics. Upon TMV infection, total POX activity was increased, accompanied by the induction of two isoPOXs with a moderately anionic nature (pI 5.65 and 6.1, respectively) in tobacco leaves (van Loon and Geelen 1971; Lagrimini and Rothstein 1987). Although the anionic POXs (pI 3.5 and 3.75) were not induced by TMV infection at both activity and mRNA levels (Lagrimini and Rothstein 1987; Ward et al. 1991), Stintzi et al. (1993) reported that the two TMV-inducible isoPOXs with the molecular mass of 39 and $40 \mathrm{kDa}$ have amino acid sequences identical to that of the anionic POX (pI 3.5). Since the 39- and 40-kDa POXs were only partially sequenced, it is not clear that they are really identical to the anionic POX (pI 3.5). Thus, there are no reports on the defined pathogen-inducible POX genes, to our knowledge.

To study pathogen-inducible isoPOXs in tobacco, we isolated novel cDNAs encoding putative POXs from a cDNA library prepared from TMV-infected tobacco leaves (Hiraga et al. 1999). Amino acid sequence alignment with known POXs revealed that one cDNA (tpoxC1) encodes a protein with the characteristic primary structure frequently found in pathogeninducible POXs from other plant species (Chittoor et al. 1999). Here, we describe the induction of the tpoxC1 gene by TMV-induced HR and its unique expression profile compared with classical tobacco acidic and basic PR genes, especially in response to defense-related signal compounds such as SA, methyl jasmonate (MeJA), ethephon, and Spm.

\section{RESULTS}

\section{Genomic organization of the tpoxC1 gene.}

Genomic DNAs from Nicotiana tabacum cv. Samsun NN, the source of tpoxC1 cDNA, and its parental species, $N$. sylvestris and $N$. tomentosiformis, were subjected to gel blot analysis to reveal the genomic organization of the tpoxC1 gene (Fig. 1). The one or two hybridization signals found in the genomic DNA from $N$. tabacum digested with EcoRI, $H$ HindII, and $\mathrm{XbaI}$ suggest that tpoxCl exists as a single copy. The mobility of the most intense signal in the $N$. tabacum genome was almost the same as that from $N$. sylvestris. Thus, the tpoxCl gene is considered to have originated from the $N$. sylvestris genome. A less intense signal in $N$. tomentosiformis indicates the existence of a closely related gene in the Nicotiana species.

\section{Organ-specific expression of the tpoxC1 gene.}

In healthy tobacco plants $(50 \mathrm{~cm}$ in height), tpoxC1 transcripts accumulated at a low level in roots, a trace level in flowers, and undetectable levels in upper leaves, lower leaves, stems, seeds, and shoot apices (Fig. 2). In contrast, the transcript for anionic POX, which was originally isolated by Lagrimini et al. (1987) and designated as tobacco PR-9 (van Loon et al. 1994), was abundant in almost all organs except for seeds, especially in stems and lower leaves (Fig. 2).

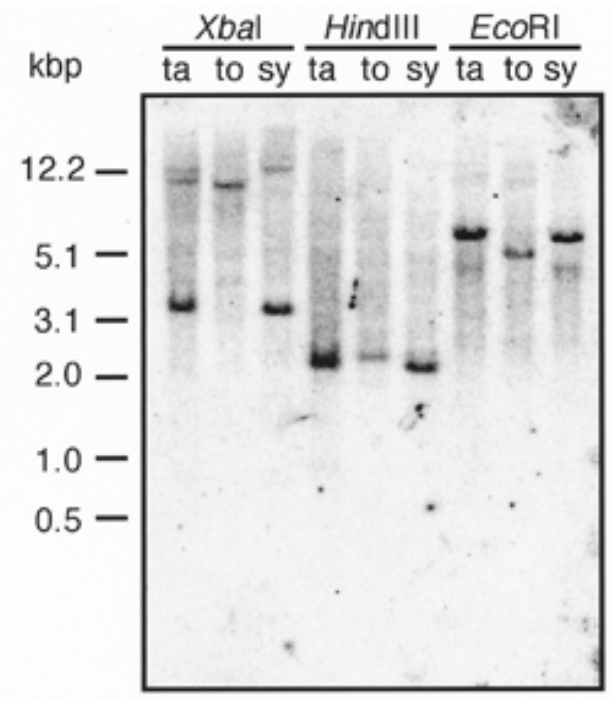

Fig. 1. Genomic DNA gel blot analysis of the tpoxC1 gene. Genomic DNAs from Nicotiana tabacum (ta), $N$. tomentosiformis (to), and $N$. sylvestris (sy) were subjected to analysis as described in Materials and Methods. The image was visualized by PhosphorImager SI.

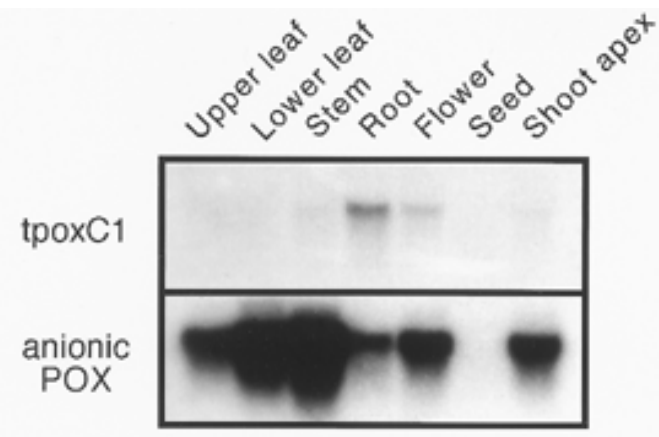

Fig. 2. Organ-specific expression of the tpoxC1 gene. Total RNAs (20 $\mu \mathrm{g}$ per lane) were isolated from organs of tobacco plants $(50 \mathrm{~cm}$ in height). Expression levels of tpoxC1 and anionic POX (Lagrimini et al. 1987) genes were monitored by RNA gel blot analysis as described in Materials and Methods. The images were visualized by autoradiography. 


\section{HR-dependent induction of tpox $C 1$ gene expression in TMV-infected leaves.}

Transcript levels of tpoxC1 and PR-1 genes were monitored with TMV- or mock-inoculated leaves incubated at $20^{\circ} \mathrm{C}$, a permissive temperature for the necrotic lesion formation that occurs as a result of the $N$ gene-mediated HR. Under these conditions, necrotic lesions appeared at about $32 \mathrm{~h}$ after TMV inoculation and increased in size with time. As shown in Figure 3, tpoxC1 mRNA levels increased remarkably with the development of necrotic lesions in TMV-inoculated leaves but not in mock-inoculated leaves. The expression profile of an acidic PR-1 gene $(P R-1 a)$ was similar but accumulation of the transcript was a little faster, compared with that of tpoxC1. The transcript level of a basic PR-1 gene $(P R B-1 b)$ was significantly increased only by wounding (mock-inoculation) and enhanced by necrotic lesion formation. Although the expression level of all three genes studied here increased depending on the development of necrotic lesions, the induction kinetics seem to differ.

Then, we compared the expression profiles of these genes with the synchronous HR inducing system: TMV-inoculated leaves were incubated for $30 \mathrm{~h}$ at $30^{\circ} \mathrm{C}$, under which conditions TMV multiplies without $\mathrm{HR}$, and then at $20^{\circ} \mathrm{C}$ to induce the formation of synchronous necrotic lesions (Fig. 4A). Transcript of the tpoxC1 gene was detected at $9 \mathrm{~h}$ after the temperature shift, coinciding with the appearance of necrotic lesions, peaked at $36 \mathrm{~h}$, and decreased thereafter, while no signal was found in mock-inoculated leaves (Fig. 4B). When we used Samsun nn tobacco plants, which lack the $N$ gene, no induced expression of the tpoxC1 gene was observed even at $48 \mathrm{~h}$ after the temperature shift in TMV-inoculated leaves, nor in mock-inoculated leaves (data not shown). The expression of the anionic POX was suppressed slightly in both mock- and TMV-inoculated leaves after the temperature shift, as reported previously (Ward et al. 1991). Similarly to tpoxC1, acidic PR1 was induced in TMV-infected Samsun NN leaves, but not in mock-inoculated leaves. On the wound-inducible basic PR-1

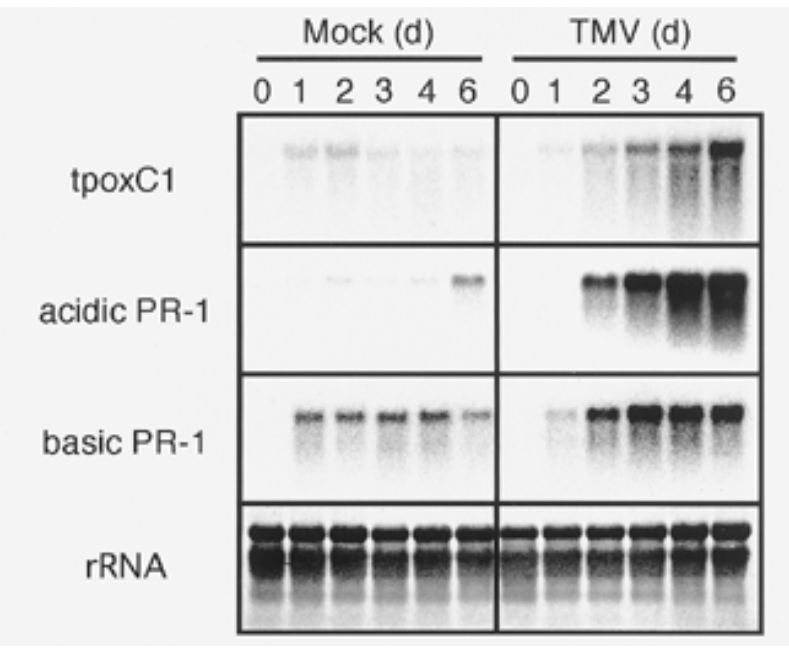

Fig. 3. Induction of tpoxC1 and PR-1 genes in Tobacco mosaic virus (TMV)-infected tobacco leaves at $20^{\circ} \mathrm{C}$. Total RNAs $(20 \mu \mathrm{g}$ per lane) were isolated from leaves harvested at the indicated time points. Expression levels of tpoxC1 and PR-1 genes were monitored by RNA gel blot analysis as described in Materials and Methods. The images were visualized by PhosphorImager SI. gene, the effect of the wounding by inoculation remained until soon after the temperature shift and the transcript level bottomed out at $12 \mathrm{~h}$ in mock-inoculated leaves. In TMVinoculated leaves the transcript level of basic PR-1 gene was enhanced accompanying necrotic lesion formation after the temperature shift.

\section{Unique response of the tpox $C 1$ gene to $N$ gene-mediated HR signals.}

In TMV-inoculated Samsun NN tobacco leaves, the timing of tpoxC1 induction and the appearance of necrotic lesions coincided (Fig. 4B), while no induction was observed in Samsun $\mathrm{nn}$ tobacco leaves, suggesting that the expression of tpox $C 1$ depends on the $N$ gene-mediated HR signals.

To analyze the response of the tpoxCl gene to HR, TMVinoculated leaves were incubated for $40 \mathrm{~h}$ at $30^{\circ} \mathrm{C}$, transiently shifted to $20^{\circ} \mathrm{C}$, and then returned back to $30^{\circ} \mathrm{C}$ (Fig. $5 \mathrm{~A}$ ). Incubation at $20^{\circ} \mathrm{C}$ for more than $4 \mathrm{~h}$ induces signals sufficient for necrotic lesion formation depending on TMV infection and the $N$ gene. In this system, 6 to $8 \mathrm{~h}$ of transient $20^{\circ} \mathrm{C}$ treatment resulted in more intense necrotic lesions $24 \mathrm{~h}$ after the temperature shift (16 to $18 \mathrm{~h}$ after the shift back to $30^{\circ} \mathrm{C}$ ) than constant $20^{\circ} \mathrm{C}$ incubation for $24 \mathrm{~h}$ (Ohtsubo et al. 1999). Expression of tpoxCl was induced by $4 \mathrm{~h}$ of $20^{\circ} \mathrm{C}$ treatment and the level increased gradually on prolonged $20^{\circ} \mathrm{C}$ treatment, showing a similar expression pattern with the tobacco proteinase inhibitor (PI)-II gene (Fig. 5B). By contrast, expression levels of both acidic and basic PR-1 genes peaked at $6 \mathrm{~h}$ of treatment, and decreased after longer $20^{\circ} \mathrm{C}$ treatment (Fig. 5B), correlating with the intensity of necrotic lesions (Fig. 5A).

To study the response of tpoxCl to defense-related signal molecules, we treated tobacco leaf disks with SA, MeJA,

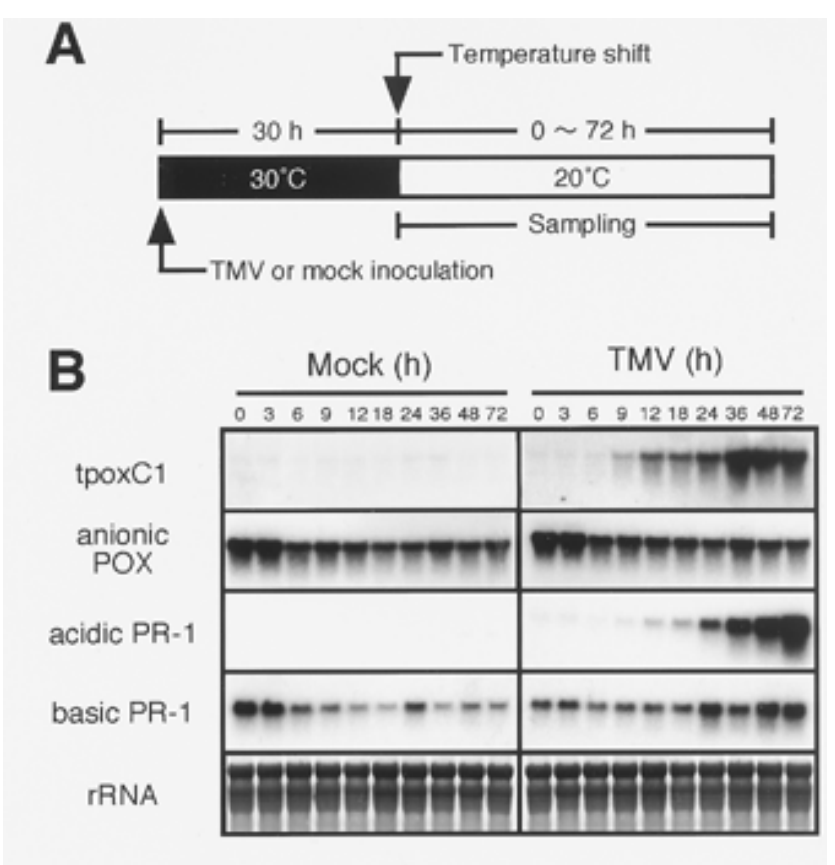

Fig. 4. Expression of tobacco POX and PR-1 genes during synchronous hypersensitive response. A, Time schedule for temperature treatment and sampling. Tobacco mosaic virus (TMV)- or mock-inoculated leaves were incubated for $30 \mathrm{~h}$ at $30^{\circ} \mathrm{C}$ and then at $20^{\circ} \mathrm{C}$. B, RNA gel blot analysis of POX and PR-1 genes in Samsun NN tobacco plants (20 $\mu \mathrm{g}$ per lane). The images were visualized by autoradiography. 
ethephon, and Spm, and analyzed the expression levels of tpoxC1 and PR-1 genes (Fig. 6). Transcript for acidic PR-1, a representative acidic-type PR protein, was induced by SA and $\mathrm{Spm}$ in a dose-dependent manner, while MeJA and ethephon treatments had no apparent effect after $48 \mathrm{~h}$. Transcript for basic PR-1, a representative basic-type PR protein, was induced $48 \mathrm{~h}$ after wounding, and the wound-induced expression was suppressed in the presence of $1 \mathrm{mM}$ SA. In contrast, treatment with MeJA, ethephon, and Spm enhanced the wound-induced basic PR gene expression in a dose-dependent manner. Unlike the PR-1 genes, tpoxC1 did not respond to $\mathrm{SA}, \mathrm{MeJA}$, or ethephon at all. Spm at 100 and $500 \mu \mathrm{M}$ induced tpoxCl gene expression at low levels.

\section{Absence of systemic tpoxC1 gene induction in uninoculated upper leaves.}

When lower tobacco leaves were infected with necrotizing pathogens, the expression of both acidic and basic PR genes was systemically induced in upper uninoculated leaves (Ward

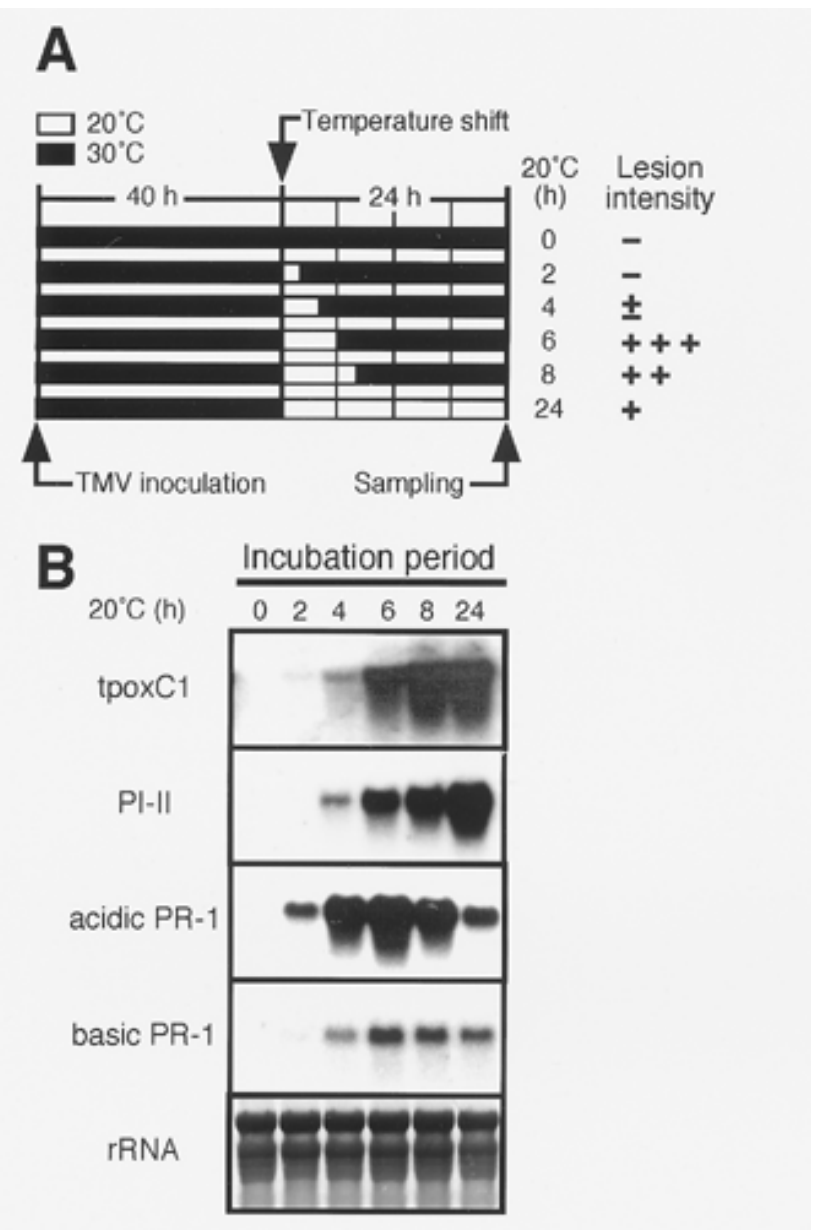

Fig. 5. Response of tpoxC1, PI-II, and PR-1 genes to transient $20^{\circ} \mathrm{C}$ treatment in Tobacco mosaic virus (TMV)-inoculated leaves. A, Time schedule for the temperature treatment and sampling. TMV-inoculated leaves were incubated at $30^{\circ} \mathrm{C}$ for $40 \mathrm{~h}$, then at $20^{\circ} \mathrm{C}$ for an appropriate period, and finally at $30^{\circ} \mathrm{C}$ again. All leaves were harvested $24 \mathrm{~h}$ after the temperature shift to $20^{\circ} \mathrm{C}$. Intensity of the necrotic lesions was evaluated by the naked eye at $24 \mathrm{~h}$ after the temperature shift. B, RNA gel blot analysis of tpoxC1, PI-II, and PR-1 genes (20 $\mu \mathrm{g}$ per lane). The images were visualized by autoradiography. et al. 1991). POX activity has also been indicated to be enhanced systemically (Simons and Ross 1970; Lagrimini and Rothstein 1987). In the case of the tpoxC1 gene, we could not detect the transcript at all in the upper uninoculated leaves 7 days after TMV inoculation of the lower leaves, while both acidic and basic PR-1 genes were apparently induced systemically in uninoculated leaves (Fig. 7).

\section{DISCUSSION}

We describe here a pathogen-inducible tobacco POX gene (tpoxC1) that does not respond to general defense-related signal compounds. Similar to that of tobacco PR genes, induction of tpoxCl depends on the $\mathrm{N}$-gene mediated HR that occurs at a permissive temperature for the $N$ resistance gene $\left(\leq 24^{\circ} \mathrm{C}\right)$ in $\mathrm{TMV}$-infected tobacco leaves undergoing necrotic lesion formation.

We studied the response of tpoxCl to HR with three different HR inducing systems. The first is $20^{\circ} \mathrm{C}$ constant treatment,

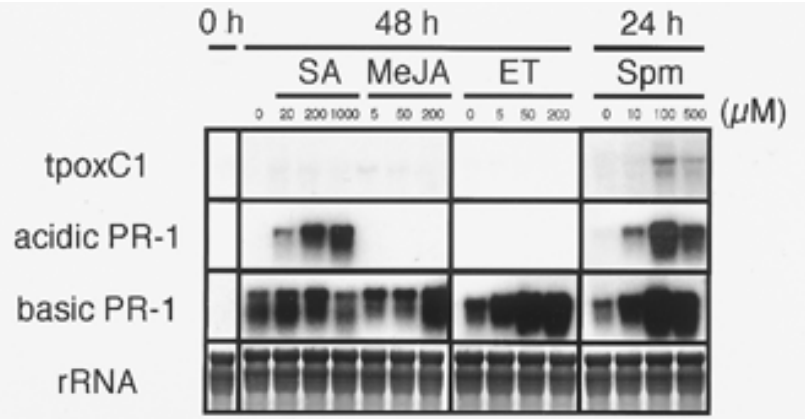

Fig. 6. Response of tpoxC1 and PR-1 genes to hypersensitive response (HR)-related signal compounds. Leaf disks (20.5 mm in diameter) were floated on the solutions containing salicylic acid (SA), methyl jasmonate (MeJA), ethephon (ET), and spermine (Spm) at $20^{\circ} \mathrm{C}$. Expression levels of tpoxC1 and PR-1 genes at $48 \mathrm{~h}$ (for SA, MeJA, and ET) or $24 \mathrm{~h}$ (for $\mathrm{Spm}$ ) were monitored by RNA gel blot analysis as described in Materials and Methods $(20 \mu \mathrm{g}$ per lane). The images were visualized by autoradiography.

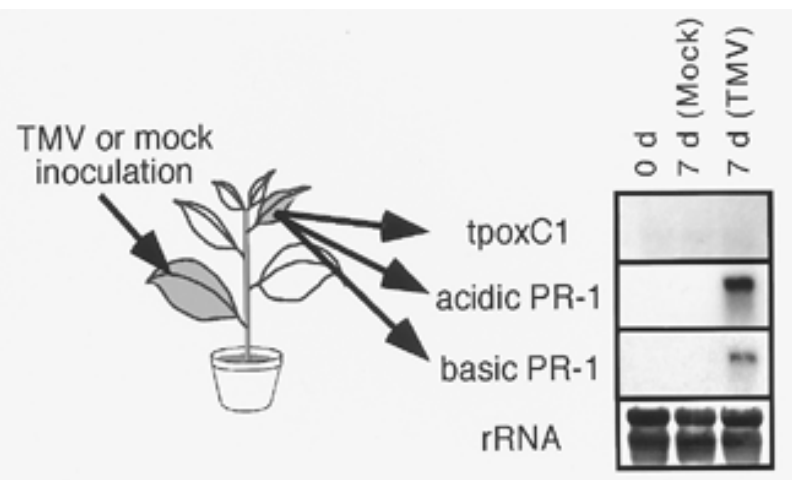

Fig. 7. Systemic expression of tpoxCl and PR-1 genes in Tobacco mosaic virus (TMV)-infected tobacco plants. Lower leaves (a leaf per plant) of tobacco plants (20 cm in height) were inoculated with TMV and upper uninoculated leaves were harvested at 0 or 7 days after inoculation. As a control, upper leaves were harvested at 7 days after mock-inoculation of lower leaves (a leaf per plant). Expression levels of tpoxC1 and PR-1 genes were monitored by RNA gel blot analysis as described in materials and methods ( $20 \mu \mathrm{g}$ per lane). The images were visualized by autoradiography. 
which induces continuous HR accompanied by normal necrotic lesion formation. The second is a temperature shift from 30 to $20^{\circ} \mathrm{C}$, which induces synchronous $\mathrm{HR}$ at first and then continuous HR: necrotic lesions synchronously appear $9 \mathrm{~h}$ after the temperature shift and increase in size gradually at $20^{\circ} \mathrm{C}$. The third is transient $20^{\circ} \mathrm{C}$ treatment $(\geq 4 \mathrm{~h})$, which induces synchronous HR within $9 \mathrm{~h}$, but TMV escapes from necrotic lesions and spreads to neighboring uninfected cells on subsequent $30^{\circ} \mathrm{C}$ treatment.

Expression of tpoxCl was induced by all three systems. However, the response of tpoxC1 to these HRs was not the same as those of PR-1 genes, which are frequently used as marker genes for HR. The difference was obvious with the third system, i.e., transient $20^{\circ} \mathrm{C}$ treatment. The levels of tpoxCl and PI-II transcripts were increased with the length of transient $20^{\circ} \mathrm{C}$ treatment. However, the levels of PR-1 transcripts peaked at $6 \mathrm{~h}$ of treatment, and decreased with longer treatment. Such response to transient $20^{\circ} \mathrm{C}$ incubation seems to correlate with the intensity of necrotic lesions. These results suggest that tpoxCl and PI-II expression is induced by continued $N$ gene-mediated signaling, while the induction of PR-1 genes depends on the formation and intensity of necrotic lesions.

The profile of the response of tpoxCl to the signal compounds that accumulate in the leaves infected with necrotizing pathogens was unique, compared with that of other defenserelated genes. Unlike acidic PR genes, tpoxC1 did not respond to SA. MeJA and ethephon, which are effective inducers for basic PR and PI-II genes (Balandin et al. 1995; Niki et al. 1998), did not activate tpoxC1 expression, as would be expected from the weak response of this gene to wounding. Spm was originally identified as an inducer for acidic PR-1, -2, -3, and -5 proteins (Yamakawa et al. 1998). In this paper, we originally indicated that $\mathrm{Spm}$ is an endogenous inducer for both tpoxC1 and basic PR genes expression. The PR-1 to -5 proteins (Memelink et al. 1990; Niki et al 1998), PR-11 (Melchers et al. 1994), and other defense-related proteins such as extensin (Memelink et al. 1993), have been reported to be induced by SA, jasmonates, or ethephon in tobacco plants. The insensitivity of tpoxCl to these compounds seems to be unique among tobacco defense-related genes. These results suggest the occurrence of unknown inducer(s) for tpoxCl in HR.

TMV-induced expression of tpoxC1 was observed in $\mathrm{NN}$ but not in nn tobacco leaves, suggesting a possible association with the resistance. At a constant $22^{\circ} \mathrm{C}$, TMV becomes restricted to the area in or around the necrotic lesions, while it easily escapes from necrotic lesions and spreads to noninfected, adjacent cells once the leaves are transferred to $32^{\circ} \mathrm{C}$ (Weststeijn 1981). Thus, the increase in tpoxC1 transcript on prolonged, transient $20^{\circ} \mathrm{C}$ treatment may also support a possible defensive role for the gene product under temperatures at which the $N$ gene is functional. The presence of $\mathrm{N}$-terminal signal peptide in the tpoxC1 gene product (Hiraga et al 1999) suggests that tpoxC1 is secreted outside of the cells and may function for pathogen resistance in cell walls or intercellular spaces. Combined studies on tpoxCl with transgenic, cytochemical, and enzymological approaches would provide further information on the defensive function of the gene product.

It remains to be elucidated how many defense-related genes are activated coordinately and specifically in HR and how the gene products function against the multiplication and spread of pathogens. A well-organized and orchestrated expression of PR genes or other defense-related genes, including tpoxC1, would be important for an effective self-defense of host plants against pathogen-attack. The unique responses of tpoxCl to HR-associated signals suggest some unknown mechanism behind the expression of defense-related genes.

\section{MATERIALS AND METHODS}

\section{Plant material and pathogen inoculation.}

Tobacco plants (Nicotiana tabacum cv. Samsun NN and cv. Samsun nn) were grown in a temperature-controlled greenhouse at 20 to $30^{\circ} \mathrm{C}$. Fully expanded upper leaves from 2month-old tobacco plants were used for all experiments except for the examination of organ specific expression.

For virus infection, tobacco leaves were inoculated with a $10 \mu \mathrm{g}$ of TMV per ml suspension and incubated at 20 or $30^{\circ} \mathrm{C}$ under continuous light at $100 \mu \mathrm{E} \cdot \mathrm{s}^{-1} \cdot \mathrm{m}^{-1}$.

\section{Chemical treatments.}

Leaf disks (20.5 $\mathrm{mm}$ in diameter) were floated on the chemical solutions and incubated at $20^{\circ} \mathrm{C}$ under continuous light at $100 \mu \mathrm{E} \cdot \mathrm{s}^{-1} \cdot \mathrm{m}^{-1}$. SA solutions were adjusted to $\mathrm{pH}$ 7.0 with $\mathrm{NaOH}$. Ethephon and Spm were dissolved in 10 $\mathrm{mM}$ MES (2-morpholinoethansulfonic acid) at $\mathrm{pH} 5.5$ and 7.5 , respectively.

\section{DNA gel blot analysis.}

Tobacco genomic DNAs $(10 \mu \mathrm{g})$ were digested with EcoRI, HindIII, and $X b a \mathrm{I}$, fractionated in a $0.7 \%$ agarose gel and blotted onto a nylon membrane (Sambrook et al. 1989). Hybridization was performed with ${ }^{32} \mathrm{P}$-labeled tpoxC1 cDNA as described previously (Church and Gilbert 1984). Bovine serum albumin (BSA) was omitted from the hybridization buffer and the membrane was washed stringently at $65^{\circ} \mathrm{C}$ for $20 \mathrm{~min}$ in $0.2 \times \mathrm{SSC}(1 \times \mathrm{SSC}$ : $0.15 \mathrm{M} \mathrm{NaCl}$ and $0.015 \mathrm{M}$ sodium citrate) containing $0.1 \%$ (wt/vol) SDS (sodium dodecyl sulfate). The image was visualized by PhosphorImager SI (Molecular Dynamics Japan, Tokyo).

\section{RNA gel blot analysis.}

Tobacco organs were frozen in liquid nitrogen immediately after sampling and stored at $-80^{\circ} \mathrm{C}$. Total RNA was isolated by the ATA method (Nagy et al. 1988). Denatured total RNAs (20 $\mu \mathrm{g}$ per lane) were separated in $1.2 \%$ agarose gels containing formaldehyde and blotted onto nylon membranes (Sambrook et al. 1989). Blots were hybridized with ${ }^{32} \mathrm{P}-$ labeled full length POX cDNAs and 3' untranslated regions of acidic (PR-1a; Matsuoka et al. 1987), basic (PRB-1b; Eyal et al. 1992) PR-1 and PI-II (Balandin et al. 1995) cDNAs at $42^{\circ} \mathrm{C}$ for $16 \mathrm{~h}$ in a solution containing $50 \mathrm{mM}$ Tris- $\mathrm{HCl}(\mathrm{pH}$ 7.5), $1 \mathrm{mM}$ EDTA, $1 \times$ Denhardt's solution (0.02\% Ficoll, $0.02 \%$ polyvinylpyrrolidone, and $0.02 \% \mathrm{BSA}), 0.5 \% \mathrm{SDS}, 3 \times$ $\mathrm{SSC}, 50 \%$ deionized formamide, and $0.1 \mathrm{mg}$ of denatured salmon sperm DNA per ml. The membrane was washed with $2 \times$ SSC containing $0.1 \%$ SDS once for $5 \mathrm{~min}$ and twice for 10 $\mathrm{min}$ at room temperature and then with $1 \times$ SSC containing $0.1 \%$ SDS 3 times for $15 \mathrm{~min}$ at $65^{\circ} \mathrm{C}$. Images were visualized by autoradiograhpy or PhosphorImager SI. Equal loading of RNAs was confirmed by monitoring the levels of ribosomal 
RNA (rRNA) stained with methylene blue (Sambrook et al. 1989).

\section{ACKNOWLEDGMENTS}

We thank the members of our laboratories for valuable discussion. We are also grateful to Y. Gotoh, H. Ochiai, and Y. Naito for maintenance of plants. This work was partly supported by grants from the COE (Center of Excellence) project, Ministry of Science and Technology of Japan.

\section{LITERATURE CITED}

Balandin, T., van der Does, C., Albert, J.-M. B., Bol, J. F., and Linthorst, H. J. M. 1995. Structure and induction pattern of a novel proteinase inhibitor class II gene of tobacco. Plant Mol. Biol. 27:1197-1204.

Bolwell, G. P., Butt, V. S., Davies, D. R., and Zimmerlin, A. 1995. The origin of the oxidative burst in plants. Free Radical Res. 23:517-532.

Bowles, D. J. 1990. Defense-related proteins in higher plants. Annu. Rev. Biochem. 59:837-907.

Brederode, F. T., Linthorst, H. J. M., and Bol, J. F. 1991. Differential induction of acquired resistance and PR gene expression in tobacco by virus infection, ethephon treatment, UV light and wounding. Plant Mol. Biol. 17:1117-1125.

Chittoor, J. M., Leach, J. E., and White, F. F. 1997. Differential induction of a peroxidase gene family during infection of rice by Xanthomonas oryzae pv. oryzae. Mol. Plant-Microbe Interact. 10:861-871.

Chittoor, J. M., Leach, J. E., and White, F. F. 1999. Induction of peroxidase during defense against pathogens. Pages 171-193 in: Pathogenesis-Related Proteins in Plants. S. K. Datta and S. Muthukrishnan, eds. CRC, Boca Raton, FL.

Church, G. M., and Gilbert, W. 1984. Genomic sequencing. Proc. Natl. Acad. Sci. USA 81:1991-1995.

Curtis, M. D., Rae, A. L., Rusu, A. G., Harrison, S. J., and Manners, J. M. 1997. A peroxidase gene promoter induced by phytopathogens and methyl jasmonate in transgenic plants. Mol. Plant-Microbe Interact. 10:326-338.

Eyal, Y., Sagee, O., and Fluhr, R. 1992. Dark-induced accumulation of a basic pathogenesis-related (PR-1) transcript and a light requirement for its induction by ethylene. Plant Mol. Biol. 19:589-599.

Fry, S. C. 1986. Cross-linking of matrix polymers in the growing cell walls of angiosperms. Annu. Rev. Plant Physiol. 37:165-186.

Gazaryan, I. G., and Lagrimini, L. M. 1996. Tobacco anionic peroxidase overexpressed in transgenic plants: Aerobic oxidation of indole-3acetic acid. Phytochemistry 42:1271-1278.

Harrison, S. J., Curtis, M. D., McIntyre, C. L., Maclean, D. J., and Manners, J. M. 1995. Differential expression of peroxidase isogenes during early stages of infection of the tropical forage legume Stylosanthes humilis by Colletotrichum gloeosporioides. Mol. Plant-Microbe Interact. 8:398-406.

Hiraga, S., Ito, H., Matsui, H., Honma, M., and Ohashi, Y. 1999. cDNA sequences for two novel tobacco peroxidase isoenzymes (accession nos. AB027752 and AB027753) (PGR 99-109). Plant Physiol. 120: 1205.

Kristensen, B. K., Bloch, H., and Rasmussen, S. K. 1999. Barley coleoptile peroxidases. Purification, molecular cloning, and induction by pathogens. Plant Physiol. 120:501-512.

Lagrimini, L. M. 1991. Wound-induced deposition of polyphenols in transgenic plants overexpressing peroxidase. Plant Physiol. 96:577583.

Lagrimini, L. M., Burkhart, W., Moyer, M., and Rothstein, S. 1987. Molecular cloning of complementary DNA encoding the ligninforming peroxidase from tobacco: Molecular analysis and tissuespecific expression. Proc. Natl. Acad. Sci. USA 84:7542-7546.

Lagrimini, L. M., Gingas, V., Finger, F., Rothstein, S., and Liu, T.-T. Y. 1997a. Characterization of antisense transformed plants deficient in the tobacco anionic peroxidase. Plant Physiol. 114:1187-1196.

Lagrimini, L. M., Joly, R. J., Dunlap, J. R., and Liu, T.-T. Y. 1997b. The consequence of peroxidase overexpression in transgenic plants on root growth and development. Plant Mol. Biol. 33:887-895.

Lagrimini, L. M., and Rothstein, S. 1987. Tissue specificity of tobacco peroxidase isozymes and their induction by wounding and tobacco mosaic virus infection. Plant Physiol. 84:438-442.
Lovrekovich, L., Lovrekovich, H., and Stahmann, M. A. 1968. Tobacco mosaic virus-induced resistance to Pseudomonas tabaci in tobacco. Phytopathology 58:1034-1035.

Malamy, J., Carr, J. P., Klessig, D. F., and Raskin, I. 1990. Salicylic acid: A likely endogenous signal in the resistance response of tobacco to viral infection. Science 250:1002-1004.

Matsuoka, M., Yamamoto, N., Kano-Murakami, Y., Tanaka, Y., Ozeki, Y., Hirano, H., Kagawa, H., Oshima, M., and Ohashi, Y. 1987. Classification and structural comparison of full-length cDNAs for pathogenesis-related proteins. Plant Physiol. 85:942-946.

Melchers, L. S., Groot, M. A., van der Knaap, J. A., Ponstein, A. S., Sela-Buurlage, M. B., Bol, J. F., Cornelissen, B. J. C., van den Elzen, P. J. M., and Linthorst, H. J. M. 1994. A new class of tobacco chitinases homologous to bacterial exo-chitinases displays antifungal activity. Plant J. 5:469-480.

Memelink, J., Linthorst, H. J. M., Schilperoort, R. A., and Hoge, J. H. C. 1990. Tobacco genes encoding acidic and basic isoforms of pathogenesis-related proteins display different expression patterns. Plant Mol. Biol. 14:119-126.

Memelink, J., Swords, K. M. M., de Kam, R. J., Schilperoort, R. A., Hoge, J. H. C., and Staehelin, L. A. 1993. Structure and regulation of tobacco extensin. Plant J. 4:1011-1022.

Nagy, F., Kay, S. A., and Chua, N. H. 1988. Analysis of gene expression in transgenic plants. Pages B4:1-29 in: Plant Molecular Biology Manual. S. B. Gelvin, R. A. Schilperoort, and D. P. S. Verma, eds. Kluwer Academic, Dordrecht, The Netherlands.

Niki, T., Mitsuhara, I., Seo, S., Ohtsubo, N., and Ohashi, Y. 1998. Antagonistic effect of salicylic acid and jasmonic acid on the expression of pathogenesis-related (PR) protein genes in wounded mature tobacco leaves. Plant Cell Physiol. 39:500-507.

Ohashi, Y., and Ohshima, M. 1992. Stress-induced expression of genes for pathogenesis-related proteins in plants. Plant Cell Physiol. 33:819826.

Ohtsubo, N., Mitsuhara, I., Koga, M., Seo, S., and Ohashi, Y. 1999. Ethylene promotes the necrotic lesion formation and basic PR gene expression in TMV-infected tobacco. Plant Cell Physiol. 40:808-817.

Rasmussen, J. B., Smith, J. A., Williams, S., Burkhart, W., Ward, E., Somerville, S. C., Ryals, J., and Hammerschmidt, R. 1995. cDNA cloning and systemic expression of acidic peroxidases associated with systemic acquired resistance to disease in cucumber. Physiol. Mol. Plant Pathol. 46:389-400.

Reimers, P. J., Guo, A., and Leach, J. E. 1992. Increased activity of a cationic peroxidase associated with an incompatible interaction between Xanthomonas oryzae pv oryzae and rice (Oryza sativa). Plant Physiol. 99:1044-1050.

Roberts, E., and Kolattukudy, P. E. 1989. Molecular cloning, nucleotide sequence, and abscisic acid induction of a suberization-associated highly anionic peroxidase. Mol. Gen. Genet. 217:223-232.

Sambrook, J., Fritsch, E. F., and Maniatis, T. A. 1989. Molecular Cloning: A Laboratory Manual. 2nd ed. Cold Spring Harbor Laboratory, Cold Spring Harbor, NY.

Schweizer, P., Buchala, A., Silverman, P., Seskar, M., Raskin, I., and Métraux, J.-P. 1997. Jasmonate-inducible genes are activated in rice by pathogen attack without a concomitant increase in endogenous jasmonic acid levels. Plant Physiol. 114:79-88.

Shimomura, T., and Dijkstra, J. 1975. The occurrence of callose during the process of local lesion formation. Neth. J. Plant Pathol. 81:107121.

Simons, T. J., and Ross, A. F. 1970. Enhanced peroxidase activity associated with induction of resistance to tobacco mosaic virus in hypersensitive tobacco. Phytopathology 60:383-384.

Stintzi, A., Heitz, T., Prasad, V., Wiedemann-Merdinoglu, S., Kauffmann, S., Geoffroy, P., Legrand, M., and Fritig, B. 1993. Plant "pathogenesis-related" proteins and their role in defense against pathogens. Biochimie 75:687-706.

Thordal-Christensen, H., Brandt, J., Cho, B. H., Rasmussen, S. K., Gregersen, P. L., Smedegaard-Petersen, V., and Collinge, D. B. 1992. cDNA cloning and characterization of two barley peroxidase transcripts induced differentially by the powdery mildew fungus Erysiphe graminis. Physiol. Mol. Plant Pathol. 40:395-409.

Thulke, O., and Conrath, U. 1998. Salicylic acid has a dual role in the activation of defense-related genes in parsley. Plant J. 14:35-42.

van Loon, L. C., and Geelen, J. L. M. C. 1971. The relation of polyphenoloxidase and peroxidase to symptom expression in tobacco var. 
"Samsun NN" after infection with tobacco mosaic virus. Acta Phytopathol. Acad. Sci. Hung. 6:9-20.

van Loon, L. C., Pierpoint, W. S., Boller, T., and Conejero, V. 1994. Recommendations for naming plant pathogenesis-related proteins. Plant Mol. Biol. Rep. 12:245-264.

van Loon, L. C., and van Strien, E. A. 1999. The families of pathogenesis-related proteins, their activities, and comparative analysis of PR-1 type proteins. Physiol. Mol. Plant Pathol. 55:85-97.

Vance, C. P., Kirk, T. K., and Sherwood, R. T. 1980. Lignification as a mechanism of disease resistance. Annu. Rev. Phytopathol. 18:259288.

Vera, P., Tornero, P., and Conejero, V. 1993. Cloning and expression analysis of a viroid-induced peroxidase from tomato plants. Mol. Plant-Microbe Interact. 6:790-794.
Ward, E. R., Uknes, S. J., Williams, S. C., Dincher, S. S., Wiederhold, D. L., Alexander, D. C., Ahl-Goy, P., Métraux, J.-P., and Ryals, J. A. 1991. Coordinate gene activity in response to agents that induce systemic acquired resistance. Plant Cell 3:1085-1094.

Weststeijn, E. A. 1981. Lesion growth and virus localization in leaves of Nicotiana tabacum cv. Xanthi nc after inoculation with tobacco mosaic virus and incubation alternately at $22^{\circ} \mathrm{C}$ and $32^{\circ} \mathrm{C}$. Physiol. Plant Pathol. 18:357-368.

Wojtaszek, P. 1997. Oxidative burst: An early plant response to pathogen infection. Biochem. J. 322:681-692.

Yamakawa, H., Kamada, H., Satoh, M., and Ohashi, Y. 1998. Spermine is a salicylate-independent endogenous inducer for both tobacco acidic pathogenesis-related proteins and resistance against tobacco mosaic virus infection. Plant Physiol. 118:1213-1222. 